\title{
Old men with prostate cancer have higher risk of Gleason score upgrading and pathological upstaging after initial diagnosis: a systematic review and meta- analysis
}

\author{
Xiaochuan Wang, Yu Zhang, Zhengguo Ji, Peiqian Yang and Ye Tian ${ }^{*}$
}

\begin{abstract}
Background: To evaluate the predictive performance of age for the risk of Gleason score change and pathologic upstaging.

Evidence acquisition: Ovid MEDLINE, Ovid Embase, and the Cochrane Library were searched from inception until May 2020. Quality of included studies was appraised utilizing the Newcastle-Ottawa Quality Assessment Scale for case-control studies. The publication bias was evaluated by funnel plots and Egger's tests.

Evidence synthesis: Our search yielded 27 studies with moderate-to-high quality including 84296 patients with mean age of 62.1 years. From biopsy to prostatectomy, upgrading and upstaging occurred in $32.3 \%$ and $9.8 \%$ of patients, respectively. Upgrading from diagnostic biopsy to confirmatory biopsy was found in $16.8 \%$. Older age was associated with a significant increased risk of upgrading (OR 1.04,95\% Cl 1.03-1.05), and similar direction of effect was found in studies focused on upgrading from diagnostic biopsy to confirmatory biopsy (OR 1.06, 95\% Cl 1.041.08). For pathologic upstaging within older men compared with younger, the pooled odds was $1.03(95 \% \mathrm{Cl} 1.01-$ 1.04).
\end{abstract}

Conclusion: Thorough consideration of age in the context of effect sizes for other factors not only prompts more accurate risk stratification but also helps providers to select optimal therapies for patients with prostate cancer.

Keywords: Systematic review, Meta-analysis, Prostate cancer, Gleason grading system, Neoplasm staging, Age

\section{Background}

Increasing prostate cancer (PCa) morbidity and mortality over past decades prompted the screening for general population and early detection for high-risk groups, as well as the improvement of manifold treatment modalities. PCa represents a spectrum of diseases that range

\footnotetext{
*Correspondence: tianye166@126.com

Department of Urology, Capital Medical University affiliated Beijing Friendship Hospital, No. 95, Yongan Road, Xicheng District, 100050 Beijing, People's Republic of China
}

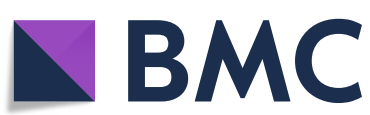

from aggressive diseases that may require treatment to non-aggressive diseases that may do not. It is universally acknowledged that overdiagnosis and overtreatment could be averted by rational use of active surveillance (AS) and observation. Within younger informed men with long expectancy of life and favorable health status, patients diagnosed with low-to-intermediate-risk PCa may be considered for AS [1]. Compared to immediate curative treatment, AS delays the onset of potential side effects and is not associated with increased $\mathrm{PCa}$

(c) The Author(s). 2021 Open Access This article is licensed under a Creative Commons Attribution 4.0 International License, which permits use, sharing, adaptation, distribution and reproduction in any medium or format, as long as you give appropriate credit to the original author(s) and the source, provide a link to the Creative Commons licence, and indicate if changes were made. The images or other third party material in this article are included in the article's Creative Commons licence, unless indicated otherwise in a credit line to the material. If material is not included in the article's Creative Commons licence and your intended use is not permitted by statutory regulation or exceeds the permitted use, you will need to obtain permission directly from the copyright holder. To view a copy of this licence, visit http://creativecommons.org/licenses/by/4.0/ The Creative Commons Public Domain Dedication waiver (http://creativecommons.org/publicdomain/zero/1.0/) applies to the data made available in this article, unless otherwise stated in a credit line to the data. 
mortality [2]. As for older patients with short expectancy of life and unfavorable health status, observation is recommended in order to maintain the quality of life and avoid the adverse events of unnecessary therapies [1]. Within this patient group, the survival rate of deferred treatment was also similar to that of immediate treatment [3]. Therefore, age is a pivotal factor for $\mathrm{PCa}$ in both risk appraisal and decision-making of treatment.

At initial diagnosis, clinical stage and Gleason score (GS) are both critical factors which provide urologists with the clinical profile of $\mathrm{PCa}$ to discriminate between indolent and aggressive disease. However, as diagnostic tools, both imaging tests and biopsy examinations inevitably have limitations in reflecting the tumor nature. Even if Gleason grading system has been modified over time, the accuracy of biopsy GS for predicting prostatectomy GS was reported to be barely satisfactory (53-74\%) [4]. Pathological upstaging (hereafter referred to as upstaging) to more aggressive diseases was also reported to affect 7.2-17.2\% of individuals [5, 6]. It has been demonstrated in large-scale studies that GS upgrading (hereafter referred to as upgrading) and upstaging were significantly associated with biochemical recurrence, distant metastasis and death from PCa [7, 8], while GS downgrading (hereafter referred to as downgrading) was a protective factor [9]. Various predictors such as prostate-specific antigen (PSA), prostate volume (PV), and number of biopsy cores were found to be associated with upgrading, downgrading or upstaging [10]. Age was also found to be predictive; however, value of odds ratio was slightly greater or less in some studies [11, 12]. Furthermore, most studies were based on monocentric databases and limited population. To address these matters, we aimed to conduct a comprehensive review of literatures and investigate the correlation between age and the risk of GS change (upgrading or downgrading) and upstaging in this systematic review and meta-analysis.

\section{Evidence acquisition}

Our review was preformed according to the Preferred Reporting Items for Systematic Reviews and Metaanalysis (PRISMA) guideline [13]. Methods and criteria were specified in advance and documented in a protocol as a reference for our investigators.

\section{Search strategy}

A comprehensive literature search for eligible records was conducted via the following databases from inception until 5th May 2020: Ovid MEDLINE, Ovid Embase, and the Cochrane Library. The full PubMed search strategy was shown in Additional Figure 1. Search terms combined $\mathrm{MeSH}$ major topic with free-words. The major terms included 'Prostatic Neoplasms,' 'Multivariate Analysis,' 'Odds Ratio,' 'Disease Progression.' Free- words included 'upgrad",' downgrad",' 'upstag", etc. which were searched in all fields. The literature search was language-restricted to English and no article-type and publication-year restrictions were included in the search. Supplementary records were identified through reviewing references of relevant literatures.

\section{Study criteria and selection}

Studies were eligible if they met the following criteria: (1) original research with experimental designs; (2) studies in the research field of PCa; (3) studies focused on the association between age and GS change or upstaging; (4) statistical methods of multivariate analysis (MVA). Major exclusive criteria included (1) reviews, metaanalysis or comments; (2) studies with unavailable fulltext such as conference abstract; (3) studies of sample size fewer than 50 patients. See Fig. 1 for the PRISMA flow diagram detailing the criteria.

\section{Study selection}

Records were retrieved from electronic databases and citations identified from relevant literatures. Obtained records were deduplicated, and the remaining were screened via titles and abstracts for full-text review. If there existed studies reporting the overlapping results (from same database and same study period), we selected the one with largest sample size. The final included literatures were evaluated in both qualitative synthesis and quantitative synthesis (meta-analysis). This whole selection procedure was conducted by two investigators (XW, YZ) independently, and disagreements were resolved by consensus and approved by a third investigator (ZJ).

\section{Data extraction}

Data were independently extracted by two investigators (XW, YZ) from included literatures and any discrepancies were resolved by consensus and approved by a third investigator (ZJ). Procedures of extraction were performed using a standardized form including study characteristics (first author, year of publication, region and interval of study, study size, and definition of endpoints), patient information (age, PSA, PV, GS, clinical T-stage, and number of cores obtained) and statistical data (adjusted odds ratio (aOR) with respective 95\% confidence interval (CI)) (shown in Tables 1 and 2).

In order to facilitate elucidation, studies were categorized into groups by definitions of study endpoints including (1) upgrading from biopsy to prostatectomy; (2) upgrading from diagnostic biopsy to confirmatory biopsy; (3) downgrading from biopsy to prostatectomy; (4) upstaging; and (5) upgrading and/or upstaging. 


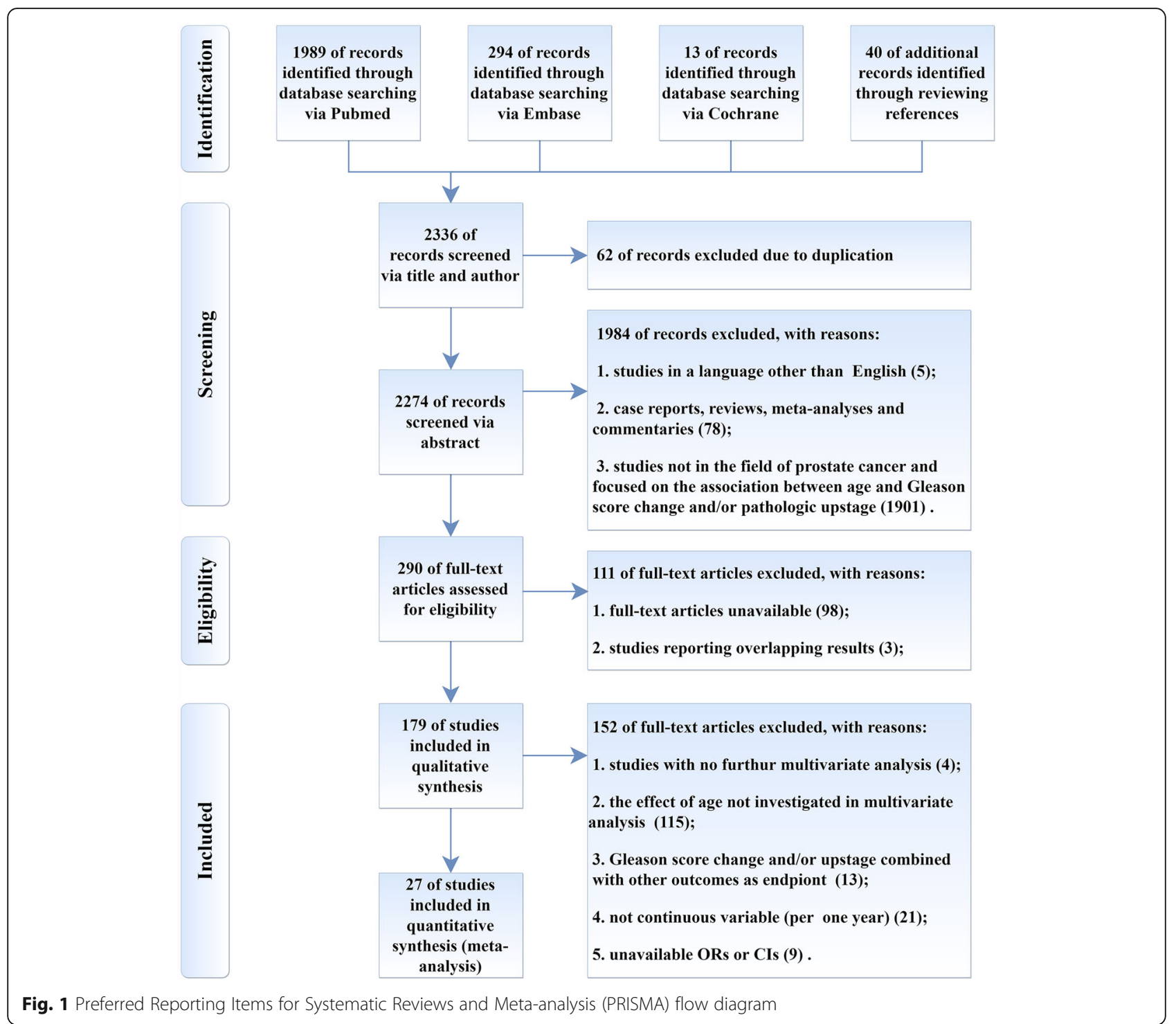

\section{Risk of bias assessment}

Two investigators (ZJ and QP) independently evaluated each included study utilizing the Newcastle-Ottawa Quality Assessment Scale (NOS) for case-control studies. Discrepancies in score assignment were later resolved by consensus.

\section{Statistical analysis}

The conversion to means of variables was roughly calculated using medians combined with interquartile range (IQR) according to Luo's methods [35]. Random effects models were used for all meta-analysis by computing log-transformed aOR (logaOR) with respective standard error (SE) to appraise the predictive performance of age on GS change and upstaging. Forest plots were depicted to provide the pooled results (i.e., the overall effect measure, Z statistic) and heterogeneity among studies. Heterogeneity was evaluated using $I^{2}$ statistic, which represented whether the variation was attributed to heterogeneity or chance. Further subgroup analysis and sensitivity analysis were carried out to find the possible sources of heterogeneity. The publication bias was evaluated by visually inspecting the asymmetry of funnel plots and subsequently quantified by Egger's tests. Tests of publication bias were only used when there were at least 10 studies included in each group otherwise power of tests were too low to distinguish chancer from real asymmetry. Tests were 2 sided and $P=0.05$ was the threshold for statistical significance. Meta-analysis and statistical tests were performed using computer software of RevMan version 5.3 and Stata version 12.0. 
Table 1 Summary data for studies comparing outcomes between biopsy and prostatectomy included for this review

\begin{tabular}{|c|c|c|c|c|c|c|c|c|c|c|c|c|}
\hline \multirow{2}{*}{$\begin{array}{l}\text { Author } \\
\text { (year ) }\end{array}$} & \multicolumn{6}{|c|}{ Study characteristic ${ }^{a}$} & \multicolumn{6}{|c|}{ Patient characteristic } \\
\hline & $\begin{array}{l}\text { Study } \\
\text { region } \\
\text { (interval) }\end{array}$ & $\begin{array}{l}\text { Study } \\
\text { size, } n\end{array}$ & $\begin{array}{l}\text { No. } \\
\text { Gleason } \\
\text { score } \\
\text { change, } n \\
(\%)\end{array}$ & $\begin{array}{l}\text { No. } \\
\text { Upstaging, } \\
n(\%)\end{array}$ & $\begin{array}{l}\text { Definition of } \\
\text { Gleason score } \\
\text { change (from } \\
\text { bGS to pGS) }\end{array}$ & $\begin{array}{l}\text { Definition } \\
\text { of } \\
\text { upstaging }\end{array}$ & $\begin{array}{l}\text { Mean } \\
\text { age, } \\
\text { years }\end{array}$ & $\begin{array}{l}\text { Mean } \\
\text { PSA, } \\
\mathrm{ng} / \\
\mathrm{mL}\end{array}$ & $\begin{array}{l}\text { Mean } \\
\mathrm{PV} \\
\mathrm{mL}\end{array}$ & bGS & $\begin{array}{l}\text { Clinical } \\
\text { T-stage }\end{array}$ & $\begin{array}{l}\text { No. cores } \\
\text { obtained, } \\
n\end{array}$ \\
\hline $\begin{array}{l}\text { Audenet } \\
2017 \text { [14] }\end{array}$ & $\begin{array}{l}\text { France } \\
(2006-2013)\end{array}$ & 1791 & 1093(61.0) & - & $\leq 6$ to $\geq 7$ & - & NA & NA & NA & $\leq 6$ & $\mathrm{~T}_{1 \mathrm{c}-3 \mathrm{~b}}$ & $10-14$ \\
\hline $\begin{array}{l}\text { Bullock } \\
2019 \text { [15] }\end{array}$ & $\begin{array}{l}\text { UK (2011- } \\
\text { 2016) }\end{array}$ & 17598 & $4489(25.5)$ & - & Any upgrading & - & 63.2 & 10.06 & NA & $\begin{array}{l}>7: \\
14 \%\end{array}$ & $\mathrm{~T}_{1-4}$ & NR \\
\hline $\begin{array}{l}\text { Dinh } \\
2015 \text { [16] }\end{array}$ & $\begin{array}{l}\text { USA (2010- } \\
\text { 2011) }\end{array}$ & 10288 & $4467(43.4)$ & 992(9.6) & $\leq 6$ to $\geq 7$ & $\begin{array}{l}\mathrm{CT}_{1-2} \mathrm{~N}_{0} \text { to } \\
\mathrm{PT}_{3 \mathrm{a}-4} \mathrm{~N}_{0-1}\end{array}$ & 59.5 & 5.2 & NA & $\leq 6$ & $\mathrm{~T}_{1 \mathrm{c}-2 \mathrm{a}}$ & 12 \\
\hline $\begin{array}{l}\text { Dinizo } \\
2018[6]\end{array}$ & $\begin{array}{l}\text { USA (2003- } \\
\text { 2014) }\end{array}$ & 2256 & 784(34.8) & $163(7.2)$ & $\leq 6$ to $\geq 7$ & $\begin{array}{l}\mathrm{CT}_{1-2} \text { to } \\
\mathrm{pT}_{3 \mathrm{a}-4}\end{array}$ & NA & NA & NA & $\leq 6$ & $T_{1-2 a}$ & $\geq 12$ \\
\hline $\begin{array}{l}\text { Epstein } \\
2012[17]\end{array}$ & $\begin{array}{l}\text { USA (2002- } \\
2010)\end{array}$ & 5071 & 1841(36.3) & - & $\leq 6$ to $\geq 7$ & - & NA & NA & NA & $\leq 6$ & $T_{1-2 a}$ & NR \\
\hline $\begin{array}{l}\text { Ferro } \\
2019 \text { [18] }\end{array}$ & $\begin{array}{l}\text { Italy (2006- } \\
\text { 2013) }\end{array}$ & 260 & $166(63.8)$ & - & $\leq 6$ to $\geq 7$ & - & 62.2 & 5.8 & 51.9 & $\begin{array}{l}>3 \\
+4: \\
13 \%\end{array}$ & $\mathrm{~T}_{1 \mathrm{c}-2 \mathrm{a}}$ & $\begin{array}{l}\text { Median 10, } \\
\text { Range 6- } \\
40\end{array}$ \\
\hline $\begin{array}{l}\text { Gondo } \\
2015[9]\end{array}$ & $\begin{array}{l}\text { USA (2005- } \\
2013)\end{array}$ & 1317 & $115(8.7)$ & - & $3+4$ to $\leq 6$ & - & NA & NA & NA & $\begin{array}{l}3+ \\
4\end{array}$ & $\mathrm{~T}_{1 \mathrm{c}-4}$ & $\geq 12$ \\
\hline $\begin{array}{l}\text { Jalloh } \\
2015 \text { [19] }\end{array}$ & $\begin{array}{l}\text { USA (1990- } \\
\text { 2012) }\end{array}$ & 4231 & $1123(26.5)$ & 499(11.8) & $\leq 6$ to $\geq 7$ & $\begin{array}{l}\mathrm{CT}_{1-2} \mathrm{~N}_{0} \text { to } \\
\mathrm{PT}_{3 \mathrm{a}-4} \mathrm{~N}_{0-1}\end{array}$ & 59.9 & NA & NA & $\leq 6$ & $\mathrm{~T}_{1-2}$ & Mean 9.15 \\
\hline $\begin{array}{l}\text { Jeon } \\
2017 \text { [10] }\end{array}$ & $\begin{array}{l}\text { USA and } \\
\text { Korea } \\
(2006-2015)\end{array}$ & 854 & $484(56.7)$ & $88(10.3)$ & $\leq 6$ to $\geq 7$ & $\begin{array}{l}\mathrm{CT}_{1-2} \text { to } \\
\mathrm{pT}_{3 \mathrm{a}-4}\end{array}$ & NA & NA & NA & $\leq 6$ & $\mathrm{~T}_{1 c-2 a}$ & NR \\
\hline $\begin{array}{l}\text { Leeman } \\
2019[11]\end{array}$ & $\begin{array}{l}\text { Germany } \\
(1992-2017)\end{array}$ & 3571 & 115(3.2) & $245(6.9)$ & $\leq 6$ to $\geq 7$ & $\begin{array}{l}\mathrm{CT}_{1-2} \text { to } \\
\mathrm{PT}_{3 \mathrm{a}-4}\end{array}$ & NA & NA & NA & $\leq 6$ & $\mathrm{~T}_{1 \mathrm{c}-2}$ & Median 9 \\
\hline $\begin{array}{l}\text { Luzzago } \\
2018 \text { [20] }\end{array}$ & $\begin{array}{l}\text { Italy (2012- } \\
\text { 2016) }\end{array}$ & 383 & 134(35.0) & & $\begin{array}{l}\mathrm{bGS} \leq 6, \mathrm{cT}_{1-2} \mathrm{~N}_{0} \text { to } \\
\text { and/or } \mathrm{pT}_{3 \mathrm{a}-4} \mathrm{~N}_{0-1}\end{array}$ & $\mathrm{pGS} \geq 7$ & NA & NA & NA & $\leq 6$ & $\mathrm{~T}_{1 c-2 a}$ & $\geq 12$ \\
\hline $\begin{array}{l}\text { Lyon } \\
2016 \text { [21] }\end{array}$ & $\begin{array}{l}\text { USA (1999- } \\
\text { 2015) }\end{array}$ & 1256 & $647(51.5)$ & - & $\leq 6$ to $\geq 7$ & - & NA & NA & NA & $\leq 6$ & $\mathrm{~T}_{1-4}$ & $\geq 6$ \\
\hline $\begin{array}{l}\text { Kim } 2013 \\
{[22]}\end{array}$ & $\begin{array}{l}\text { Korea } \\
(2005-2011)\end{array}$ & 451 & 194(43.0) & - & $\leq 6$ to $\geq 7$ & - & 64 & 8.79 & 38.1 & $\leq 6$ & $T_{1-2}$ & $\begin{array}{l}\text { Mean 11.5, } \\
\text { Range 2- } \\
27\end{array}$ \\
\hline $\begin{array}{l}\text { Kwon } \\
2016 \text { [23] }\end{array}$ & $\begin{array}{l}\text { USA (2006- } \\
2015)\end{array}$ & 217 & $58(26.7)$ & - & $\leq 6$ to $\geq 7$ & - & NA & NA & NA & $\leq 6$ & $T_{1-2 a}$ & NR \\
\hline $\begin{array}{l}\text { Magheli } \\
2010[24]\end{array}$ & $\begin{array}{l}\text { Germany } \\
(1999-2004)\end{array}$ & 610 & $308(50.5)$ & - & $\leq 6$ to $\geq 7$ & - & NA & NA & NA & $\leq 6$ & $\mathrm{~T}_{1-2}$ & NR \\
\hline $\begin{array}{l}\text { Martin } \\
2017 \text { [25] }\end{array}$ & $\begin{array}{l}\text { USA (2005- } \\
\text { 2008) }\end{array}$ & 136 & 19(14.0) & - & $\leq 7$ to $\geq 8$ & - & NA & NA & NA & $\leq 7$ & $\mathrm{~T}_{1 \mathrm{c}-2}$ & $\geq 10$ \\
\hline $\begin{array}{l}\text { Mizuno } \\
2016[26]\end{array}$ & $\begin{array}{l}\text { Japan } \\
\text { (2005-2011) }\end{array}$ & 284 & $154(54.2)$ & & $\begin{array}{l}b G S \leq 6, c T_{1-2} \text { to } p \\
\text { or } p T_{3 a-4}\end{array}$ & $\mathrm{GS} \geq 7$ and/ & NA & NA & NA & $\leq 6$ & $\mathrm{~T}_{1 \mathrm{c}-2 \mathrm{a}}$ & NR \\
\hline \multirow{3}{*}{$\begin{array}{l}\text { Morlacco } \\
2016[5]\end{array}$} & \multirow{3}{*}{$\begin{array}{l}\text { USA (2006- } \\
\text { 2014) }\end{array}$} & \multirow[t]{3}{*}{1190} & 156(13.1) & \multirow[t]{3}{*}{ 205(17.2) } & $3+4$ to $\geq 4+3$ & $\mathrm{CT}_{1-2}$ to & \multirow[t]{3}{*}{ NA } & \multirow[t]{3}{*}{ NA } & \multirow[t]{3}{*}{ NA } & \multirow{3}{*}{$\begin{array}{l}3+ \\
4\end{array}$} & \multirow[t]{3}{*}{$\mathrm{T}_{1 \mathrm{c}-2 \mathrm{a}}$} & \multirow{3}{*}{$\begin{array}{l}\text { Median 12, } \\
\text { IQR 12-14 }\end{array}$} \\
\hline & & & 201(16.9) & & $3+4$ to $\leq 6$ & & & & & & & \\
\hline & & & $295(24.8)$ & & $\begin{array}{l}\mathrm{bGS}=3+4, \mathrm{CT}_{1-2} \mathrm{~N} \\
4+3 \text { and/or } \mathrm{pT}_{3 \mathrm{a}-4}\end{array}$ & $\begin{array}{l}10 \text { to } p G S \geq \\
N_{0-1}\end{array}$ & & & & & & \\
\hline $\begin{array}{l}\text { Oh } 2012 \\
{[27]}\end{array}$ & $\begin{array}{l}\text { Korea } \\
(2003-2010)\end{array}$ & 505 & 253(50.1) & - & $\leq 6$ to $\geq 7$ & - & 65.2 & 7.79 & 39.5 & $\leq 6$ & $\mathrm{~T}_{1 c-2 a}$ & $\geq 12$ \\
\hline $\begin{array}{l}\text { Pietzak } \\
2014 \text { [28] }\end{array}$ & $\begin{array}{l}\text { USA (1998- } \\
\text { 2008) }\end{array}$ & 400 & - & 49(12.3) & - & $\begin{array}{l}\mathrm{CT}_{1-2} \text { to } \\
\mathrm{PT}_{3 \mathrm{a}-4}\end{array}$ & NA & NA & NA & $\leq 6$ & $\mathrm{~T}_{1 \mathrm{c}-2 \mathrm{a}}$ & $\geq 10$ \\
\hline $\begin{array}{l}\text { Shoag } \\
2020[29]\end{array}$ & $\begin{array}{l}\text { USA (2010- } \\
\text { 2015) }\end{array}$ & 11025 & $2255(45.2)$ & - & Any downgrading & - & NA & NA & NA & $\begin{array}{l}6- \\
10\end{array}$ & $\mathrm{~T}_{1-3}$ & NR \\
\hline $\begin{array}{l}\text { Weiner } \\
2015 \text { [30] }\end{array}$ & $\begin{array}{l}\text { USA (2010- } \\
\text { 2011) }\end{array}$ & 17943 & $8113(45.2)$ & & $\begin{array}{l}\mathrm{bGS} \leq 6, \mathrm{cT}_{1-2} \mathrm{~N}_{0} \text { to } \\
\text { and/or } \mathrm{pT}_{3 \mathrm{a}-4} \mathrm{~N}_{0-1}\end{array}$ & $\mathrm{pGS} \geq 7$ & NA & NA & NA & $\leq 6$ & $\mathrm{~T}_{1-2 \mathrm{a}}$ & NR \\
\hline
\end{tabular}


Table 1 Summary data for studies comparing outcomes between biopsy and prostatectomy included for this review (Continued)

\begin{tabular}{|c|c|c|c|c|c|c|c|c|c|c|c|c|}
\hline \multirow{2}{*}{$\begin{array}{l}\text { Author } \\
\text { (year) }\end{array}$} & \multicolumn{6}{|c|}{ Study characteristic ${ }^{a}$} & \multicolumn{6}{|c|}{ Patient characteristic } \\
\hline & $\begin{array}{l}\text { Study } \\
\text { region } \\
\text { (interval) }\end{array}$ & $\begin{array}{l}\text { Study } \\
\text { size, } n\end{array}$ & $\begin{array}{l}\text { No. } \\
\text { Gleason } \\
\text { score } \\
\text { change, } n \\
(\%)\end{array}$ & $\begin{array}{l}\text { No. } \\
\text { Upstaging, } \\
n(\%)\end{array}$ & $\begin{array}{l}\text { Definition of } \\
\text { Gleason score } \\
\text { change (from } \\
\text { bGS to pGS) }\end{array}$ & $\begin{array}{l}\text { Definition } \\
\text { of } \\
\text { upstaging }\end{array}$ & $\begin{array}{l}\text { Mean } \\
\text { age, } \\
\text { years }\end{array}$ & $\begin{array}{l}\text { Mean } \\
\text { PSA, } \\
\mathrm{ng} / \\
\mathrm{mL}\end{array}$ & $\begin{array}{l}\text { Mean } \\
\mathrm{PV}, \\
\mathrm{mL}\end{array}$ & bGS & $\begin{array}{l}\text { Clinical } \\
\text { T-stage }\end{array}$ & $\begin{array}{l}\text { No. cores } \\
\text { obtained, } \\
n\end{array}$ \\
\hline $\begin{array}{l}\text { Wong } \\
2012[31]\end{array}$ & $\begin{array}{l}\text { Canada, } \\
\text { Australia } \\
\text { and UK } \\
\text { (2003-2010) }\end{array}$ & 644 & 333 & & $\begin{array}{l}\mathrm{bGS} \leq 6, \mathrm{cT}_{1-2} \text { to } \mathrm{pG} \\
\text { or } \mathrm{pT}_{3 \mathrm{a}-4}\end{array}$ & $\mathrm{~S} S \geq 8$ and/ & NA & NA & NA & $\leq 6$ & $\mathrm{~T}_{1-2 \mathrm{a}}$ & $8-12$ \\
\hline $\begin{array}{l}\text { Zanaty } \\
2018 \text { [12] }\end{array}$ & $\begin{array}{l}\text { Canada } \\
(2006-2014)\end{array}$ & 237 & $134(56.5)$ & - & $\leq 6$ to $\geq 7$ & - & 58.6 & 38.4 & 5.03 & NR & $\mathrm{T}_{1 \mathrm{c}-2 \mathrm{a}}$ & NR \\
\hline
\end{tabular}

PSA prostate-specific antigen, $P V$ prostate volume, $b G S$ biopsy Gleason score, $p G S$ prostatectomy Gleason score, NA not available, IQR interquartile range ${ }^{\mathrm{a} A l l}$ studies were case-control designs

\section{Evidence synthesis}

There were 2296 eligible records retrieved from electronic databases and additional 40 identified from pertinent references. Of retrieved records, 62 were deduplicated and the remaining 2274 were screened for fulltext review via titles and abstracts. Two hundred ninety articles were selected after screening, and 27 literatures were finally included according to exclusive criteria. The reasons for exclusion were provided in PRISMA flow diagram (shown in Fig. 1).

\section{Study description}

Included 27 literatures were all retrospective studies of case-control designs which were published between 2010 and 2020. Eighteen literatures were monocentric studies, 4 were multicentric, and 5 were from administrative databases. Total sample size of this review was 84,296 patients in a time span of 28 years (1990-2018). Irrespective of literatures based on administrative databases, sample size was 23,211 patients. There were 18 studies from North America, 7 from Europe, 4 from Asia, and 1 from Australia. Seventeen literatures were enrolled into group of upgrading from biopsy to prostatectomy with total 48,590 patients $[5,6,10-12,14-19$,
$21-25,27]$, while 3 were enrolled into group of upgrading from diagnostic biopsy to confirmatory biopsy $(n=$ 1778) [32-34]. Three literatures were eligible for group of downgrading from biopsy to prostatectomy $(n=$ 13532) $[5,9,29], 7$ were eligible for group of upstaging $(n=22790)[5,6,10,11,16,19,28]$ and 5 were eligible for group of upgrading and/or upstaging $(n=20444)$ [5, 20, 26, 30, 31] (shown in Tables 1 and 2).

From biopsy to prostatectomy, upgrading was found in $32.3 \%$ of patients with biopsy specimens, while downgrading was found in $19.0 \%$ of patients. Upgrading from diagnostic biopsy to confirmatory biopsy was found in $16.8 \%$. Of 22,790 patients, the upstaging was found in $9.8 \%$ of organ confined diseases. Calculated with extractable data, the pooled mean age, PSA level, and PV were 62.1 years, $3.97 \mathrm{ng} / \mathrm{mL}$, and $42.1 \mathrm{~mL}$, respectively. Most patients had low-risk organ-confined $\mathrm{PCa}$ at diagnosis and underwent biopsy with extended schemes (shown in Tables 1 and 2)

\section{Risk of bias assessment}

All included literatures had low-to-moderate risk bias according to NOS scale. Three articles were rated as a total score of 5 , while the others were rated as 6 or

Table 2 Summary data for studies comparing outcomes between diagnostic biopsy and confirmatory biopsy included for this review

\begin{tabular}{|c|c|c|c|c|c|c|c|c|c|c|}
\hline \multirow{2}{*}{$\begin{array}{l}\text { Author } \\
\text { (year ) }\end{array}$} & \multicolumn{4}{|c|}{ Study characteristic ${ }^{a}$} & \multicolumn{6}{|c|}{ Patient characteristic } \\
\hline & $\begin{array}{l}\text { Study } \\
\text { region } \\
\text { (interval) }\end{array}$ & $\begin{array}{l}\text { Study } \\
\text { size, } n\end{array}$ & $\begin{array}{l}\text { No. } \\
\text { Upgrading, } \\
n(\%)\end{array}$ & $\begin{array}{l}\text { Definition of upgrading } \\
\text { (from bGS to pGS) }\end{array}$ & $\begin{array}{l}\text { Mean } \\
\text { age, } \\
\text { years }\end{array}$ & $\begin{array}{l}\text { Mean } \\
\text { PSA, ng/ } \\
\mathrm{mL}\end{array}$ & $\begin{array}{l}\text { Mean } \\
\mathrm{PV}, \mathrm{mL}\end{array}$ & bGS & $\begin{array}{l}\text { Clinical } \\
\text { T-stage }\end{array}$ & $\begin{array}{l}\text { No. cores } \\
\text { obtained, } n\end{array}$ \\
\hline $\begin{array}{l}\text { Anderson } \\
2015[32]\end{array}$ & $\begin{array}{l}\text { USA } \\
(1991-2001)\end{array}$ & 646 & $55(8.5)$ & $\leq 6$ to $\geq 7$ & NA & NA & NA & $\leq 6$ & $\mathrm{~T}_{1 \mathrm{c}-2 \mathrm{a}}$ & $\begin{array}{l}\text { Median 12, } \\
\text { IQR 11-12 }\end{array}$ \\
\hline Dai 2019 [33] & $\begin{array}{l}\text { USA } \\
(2005-2015)\end{array}$ & 406 & $85(20.9)$ & $\leq 6$ to $\geq 7$ & NA & NA & NA & $\leq 6$ & $\mathrm{~T}_{1-2}$ & 12 \\
\hline $\begin{array}{l}\text { Herrera- } \\
\text { Caceres } 2020\end{array}$ & $\begin{array}{l}\text { Canada } \\
\text { (2006-2018) }\end{array}$ & 726 & $159(21.9)$ & $\leq 6$ to $\geq 7$ & NA & NA & NA & $\leq 6$ & NA & $\begin{array}{l}\text { Median 12, } \\
\text { IQR 10-12 }\end{array}$ \\
\hline
\end{tabular}

[34]

PSA prostate-specific antigen, $P V$ prostate volume, $b G S$ biopsy Gleason score, $p G S$ prostatectomy Gleason score, NA not available, IQR interquartile range 
more. Studies with data source of administrative databases instead of original records resulted in bias of selection and inaccuracy in ascertainment of exposure. Studies not adjusting for potential confounders in MVA resulted in poor comparability, especially the excluded confounders very likely influencing discordance of GS and disease stage between initial diagnosis and final outcomes (shown in Table 3)

\section{Gleason score change}

As shown in the forest plots (shown in Fig. 2), age was found to be an independent predictor of upgrading. Older age was associated with a significant increased risk of upgrading from biopsy to prostatectomy (pooled aOR 1.04, 95\% CI 1.03-1.05; $p<0.01 ; I^{2}=76 \%$ ). According to funnel plots and Egger's tests (shown in Fig. 3 and Additional Figure 2), publication bias was observed in group of upgrading from biopsy to prostatectomy ( $p_{\text {Egger }}$ $=0.003)$. We found a similar direction of effect when we examined studies focused on upgrading from diagnostic biopsy to confirmatory biopsy (pooled aOR 1.06, 95\% CI $1.04-1.08 ; p<0.01 ; I^{2}=0 \%$ ). However, age failed to be associated with downgrading from biopsy to prostatectomy (pooled aOR 0.98, 95\% CI 0.94-1.03; $p=0.49 ; I^{2}=$ $89 \%)$.

\section{Pathologic upstaging}

The pooled adjusted odds of upstaging within older men compared with the younger men were 1.03 (95\% CI $1.01-1.04 ; p=0.002 ; I^{2}=66 \%$ ). In group of studies using upgrading combined with upstaging as endpoint, no association was found between the endpoint and age (pooled aOR 1.06, 95\% CI 0.96-1.18; $p=0.23 ; I^{2}=98 \%$ ) (shown in Fig. 2)

\section{Heterogeneity analysis}

In subgroup analysis and sensitivity analysis of upgrading (shown in Table 4), we managed to seek the source of heterogeneity. We found that $I^{2}$ statistic decreased to $67 \%$ when studies including patients of higher than cT2 were removed. Decreased heterogeneity (62\%) was also found when studies not adjusted for PV were removed. Considering small size effect, $I^{2}$ statistic decreased to $44 \%$ and $12 \%$, respectively in subgroups above after removed literatures of study size smaller than 300. After removing studies not adjusted for number of cores obtained, $I^{2}$ statistic decreased to $50 \%$. Prostate size [10, $17,18,21,22]$, number of cores [36], and disease stage $[11,12,15]$ were validated to be independent predictors of upgrading. Existence of confounders was thought to be the major reason for heterogeneity of our synthesis. As for upstaging, after removed one literature [28] of small size, $I^{2}$ statistic decreased to $0 \%$. Small size study made the pooled analysis unstable and less robust.

\section{Discussion}

In this systematic review and meta-analysis of 27 studies with moderate-to-high ranking of quality, we identified that age was an independent predictor for upgrading from biopsy to prostatectomy (aOR 1.04, 95\% CI 1.03$1.05)$ and upstaging (aOR 1.03, 95\% CI 1.01-1.04) in the patient groups who were eligible for curative treatment. For every increased year of age, there was a $4 \%$ increased risk of upgrading and 3\% of upstaging. From diagnostic biopsy to confirmatory biopsy, there was a $6 \%$ increased risk of upgrading (aOR 1.06, 95\% CI 1.04-1.08). Based on large-scale population, this review also demonstrated that upgrading, downgrading and upstaging occurred respectively in $32.3 \%, 19.0 \%$ and $9.8 \%$ of patients who underwent prostatectomy. Upgrading at confirmatory biopsy was found in $16.8 \%$ of initial biopsy.

$\mathrm{PCa}$ is a spectrum of heterogeneous diseases, some of which are so indolent to influence overall survival especially in older patients. Therefore, precise assessment of risk stratification seems to be pivotal in disease management. It has been demonstrated that upgrading and upstaging were significantly associated with biochemical recurrence, unfavorable surgical outcomes, and cancerspecific survival $[7,37,38]$. Even if the proportion of both upgrading and upstaging is small, precise risk stratification and prediction of outcomes are requisite for individualized management.

For younger individuals especially with good health status, those with low or favorable intermediate risk PCa are recommended to undergo AS rather than immediate curative therapies [1]. Even if younger patients under AS had no significant difference in treatment-free survival compared with older counterparts [39], delayed treatment can avoid side effects such as erectile and voiding dysfunction in the young. According to the findings of this review, young patients had lower risk of upgrading and upstaging. Accurate assessment of PCa may boost confidence of urologists and patients in initiation and continuation of AS protocol. For patients with low risk of upgrading and upstaging who intend to undergo definitive treatment, salvage therapies might be unnecessary to improve prognosis. Longer waits between postoperative follow-ups might be recommended. Even if the risk is relatively low, confirmatory biopsy or rebiopsy is an option before developing and implementing $\mathrm{PCa}$ management programs.

For older asymptomatic individuals with other morbidities or short life expectancy, no further therapies are indicated until symptoms occurs [1]. Provided that older patients might have higher rate of upgrading and upstaging, monitoring the course of disease need to be performed in a relatively short space of time and the delivery of palliative therapies for the development of symptoms might be earlier. Older men had a 
Table 3 Newcastle-Ottawa Quality Assessment Scale (NOS) for included case-control studies

\begin{tabular}{|c|c|c|c|c|c|c|c|c|c|}
\hline \multirow[t]{2}{*}{ Study } & \multicolumn{4}{|l|}{ Selection } & \multirow[t]{2}{*}{ Comparability } & \multicolumn{3}{|l|}{ Exposure } & \multirow{2}{*}{$\begin{array}{l}\text { Total } \\
\text { score } \\
\text { (sum } \\
\text { of } \\
\text { stars) }\end{array}$} \\
\hline & $\begin{array}{l}\text { Is the case } \\
\text { definition } \\
\text { adequate? }\end{array}$ & $\begin{array}{l}\text { Representativeness } \\
\text { of the cases }\end{array}$ & $\begin{array}{l}\text { Selection } \\
\text { of } \\
\text { Controls }\end{array}$ & $\begin{array}{l}\text { Definition } \\
\text { of } \\
\text { Controls }\end{array}$ & & $\begin{array}{l}\text { Ascertainment } \\
\text { of exposure }\end{array}$ & $\begin{array}{l}\text { Same method of } \\
\text { ascertainment for } \\
\text { cases and } \\
\text { controls }\end{array}$ & $\begin{array}{l}\text { Non- } \\
\text { response } \\
\text { rate }\end{array}$ & \\
\hline $\begin{array}{l}\text { Anderson } \\
2015 \text { [32] }\end{array}$ & $\star$ & $\star$ & $i$ & $\star$ & $\star \star$ & $\star$ & $\star$ & $\star$ & 8 \\
\hline $\begin{array}{l}\text { Audenet } \\
2017 \text { [14] }\end{array}$ & $\star$ & $\star$ & $\hat{\imath}$ & $\star$ & $\star \star$ & $\star$ & $\star$ & $\star$ & 8 \\
\hline $\begin{array}{l}\text { Bullock } \\
2019 \text { [15] }\end{array}$ & 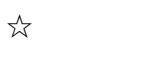 & $\star$ & $i$ & $\star$ & $\star \Delta$ & $\dot{s}$ & $\star$ & $\star$ & 5 \\
\hline $\begin{array}{l}\text { Dai } 2019 \\
{[33]}\end{array}$ & $\star$ & $\star$ & $i$ & $\star$ & $\star \star$ & $\star$ & $\star$ & $\star$ & 8 \\
\hline $\begin{array}{l}\text { Dinh } 2015 \\
\text { [16] }\end{array}$ & $i$ & $\star$ & $i$ & $\star$ & $\star \star$ & 㶦 & $\star$ & $\star$ & 6 \\
\hline $\begin{array}{l}\text { Dinizo } \\
2018 \text { [6] }\end{array}$ & $\star$ & $\star$ & $i$ & $\star$ & $\star \Delta$ & $\star$ & $\star$ & $\star$ & 7 \\
\hline $\begin{array}{l}\text { Epstein } \\
2012 \text { [17] }\end{array}$ & $\star$ & $\star$ & 弥 & $\star$ & 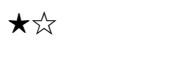 & $\star$ & $\star$ & $\star$ & 7 \\
\hline $\begin{array}{l}\text { Ferro } \\
2019 \text { [18] }\end{array}$ & $\star$ & $\star$ & 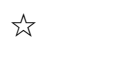 & $\star$ & $\star \star$ & $\star$ & $\star$ & $\star$ & 8 \\
\hline $\begin{array}{l}\text { Gondo } \\
2015[9]\end{array}$ & $\star$ & $\star$ & $i$ & $\star$ & $\star \star$ & $\star$ & $\star$ & $\star$ & 7 \\
\hline $\begin{array}{l}\text { Herrera- } \\
\text { Caceres } \\
2020 \text { [34] }\end{array}$ & $\star$ & $\star$ & $i$ & $\star$ & $\star \star$ & $\star$ & $\star$ & $\star$ & 7 \\
\hline $\begin{array}{l}\text { Jalloh } \\
2015 \text { [19] }\end{array}$ & $\star$ & $\star$ & $i$ & $\star$ & $\star \star$ & $\star$ & $\star$ & $\star$ & 8 \\
\hline $\begin{array}{l}\text { Jeon } 2017 \\
\text { [10] }\end{array}$ & $\star$ & $\star$ & 弥 & $\star$ & $\star \star$ & $\star$ & $\star$ & $\star$ & 8 \\
\hline $\begin{array}{l}\text { Kim } 2013 \\
{[22]}\end{array}$ & $\star$ & $\star$ & 弥 & $\star$ & $\star \star$ & $\star$ & $\star$ & $\star$ & 8 \\
\hline $\begin{array}{l}\text { Kwon } \\
2016 \text { [23] }\end{array}$ & $\star$ & $\star$ & 弥 & $\star$ & $\star \star$ & $\star$ & $\star$ & $\star$ & 8 \\
\hline $\begin{array}{l}\text { Leeman } \\
2019[11]\end{array}$ & $\star$ & $\star$ & $i$ & $\star$ & $\star \Delta$ & $\star$ & $\star$ & $\star$ & 7 \\
\hline $\begin{array}{l}\text { Luzzago } \\
2018 \text { [20] }\end{array}$ & $\star$ & $\star$ & 㶦 & $\star$ & $\star \star$ & $\star$ & $\star$ & $\star$ & 8 \\
\hline $\begin{array}{l}\text { Lyon } \\
2016 \text { [21] }\end{array}$ & $\star$ & $\star$ & 弥 & $\star$ & $\star \star$ & $\star$ & $\star$ & $\star$ & 8 \\
\hline $\begin{array}{l}\text { Magheli } \\
2010 \text { [24] }\end{array}$ & $\star$ & $\star$ & $i$ & $\star$ & $\star \Delta$ & $\star$ & $\star$ & $\star$ & 7 \\
\hline $\begin{array}{l}\text { Martin } \\
2017 \text { [25] }\end{array}$ & $\star$ & $\star$ & $i$ & $\star$ & $\star \Delta$ & $\star$ & $\star$ & $\star$ & 7 \\
\hline $\begin{array}{l}\text { Mizuno } \\
2016 \text { [26] }\end{array}$ & $\star$ & $\star$ & 约 & $\star$ & $\star \Delta$ & $\star$ & $\star$ & 岤 & 6 \\
\hline $\begin{array}{l}\text { Morlacco } \\
2016[5]\end{array}$ & $\star$ & $\star$ & 约 & $\star$ & $\star \Delta$ & $\star$ & $\star$ & $\star$ & 7 \\
\hline $\begin{array}{l}\text { Oh } 2012 \\
{[27]}\end{array}$ & $\star$ & $\star$ & 㶦 & $\star$ & $\star \star$ & $\star$ & $\star$ & $\star$ & 8 \\
\hline $\begin{array}{l}\text { Pietzak } \\
2014 \text { [28] }\end{array}$ & $\star$ & $\star$ & 弥 & $\star$ & $\star \Delta$ & $\star$ & $\star$ & $\star$ & 7 \\
\hline $\begin{array}{l}\text { Shoag } \\
2020 \text { [29] }\end{array}$ & $i$ & $\star$ & 谞 & $\star$ & $\star \Delta$ & 岤 & $\star$ & $\star$ & 5 \\
\hline Weiner & $\hat{z}$ & $\star$ & 㶦 & $\star$ & 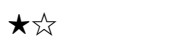 & 访 & $\star$ & $\star$ & 5 \\
\hline
\end{tabular}


Table 3 Newcastle-Ottawa Quality Assessment Scale (NOS) for included case-control studies (Continued)

\begin{tabular}{|c|c|c|c|c|c|c|c|c|c|}
\hline \multirow[t]{2}{*}{ Study } & \multicolumn{4}{|l|}{ Selection } & \multirow[t]{2}{*}{ Comparability } & \multicolumn{3}{|l|}{ Exposure } & \multirow{2}{*}{$\begin{array}{l}\text { Total } \\
\text { score } \\
\text { (sum } \\
\text { of } \\
\text { stars) }\end{array}$} \\
\hline & $\begin{array}{l}\text { Is the case } \\
\text { definition } \\
\text { adequate? }\end{array}$ & $\begin{array}{l}\text { Representativeness } \\
\text { of the cases }\end{array}$ & $\begin{array}{l}\text { Selection } \\
\text { of } \\
\text { Controls }\end{array}$ & $\begin{array}{l}\text { Definition } \\
\text { of } \\
\text { Controls }\end{array}$ & & $\begin{array}{l}\text { Ascertainment } \\
\text { of exposure }\end{array}$ & $\begin{array}{l}\text { Same method of } \\
\text { ascertainment for } \\
\text { cases and } \\
\text { controls }\end{array}$ & $\begin{array}{l}\text { Non- } \\
\text { response } \\
\text { rate }\end{array}$ & \\
\hline \multicolumn{10}{|l|}{2015 [30] } \\
\hline $\begin{array}{l}\text { Wong } \\
2012 \text { [31] }\end{array}$ & $\star$ & $\star$ & 论 & $\star$ & $\star \star$ & $\star$ & $\star$ & $\star$ & 8 \\
\hline $\begin{array}{l}\text { Zanaty } \\
2018 \text { [12] }\end{array}$ & $\star$ & $\star$ & 访 & $\star$ & $\star \star$ & $\star$ & $\star$ & $\star$ & 8 \\
\hline
\end{tabular}

significantly higher clinical stage and biopsy Gleason grade at diagnosis which was associated with poorer prognosis compared with younger men [40]. However, fewer older individuals with good quality of life might benefit from curative treatment. Thus, urologists should be reminded of high-grade $\mathrm{PCa}$ harbored in older patients and reconsider the treatment modalities before developing a treatment program.

Included literatures all have different research purposes that focused on different variables which might impact on upgrading or upstaging. Laboratory findings $[18,23]$ (such as neutrophil to lymphocyte ratios), imaging parameters [20] (such as PI-RADS score), pathological features [28] (such as number or proportion of positive biopsy cores) and other clinical factors [12] (such as years of research) were all investigated to have potential predictive performances. This might contribute to the heterogeneity of our review. Age is a basic parameter as well as a confounder which is usually adjusted for in MVA. And as such, age was validated to be an independent predictor under different circumstances.

In 2005 and 2014, amendments to the Gleason grading system by the International Society of Urological Pathology (ISUP) were recommended [41]. This has led to a closer correlation between the grade of a series of thin core biopsies and the subsequent radical prostatectomy specimen. It has been reported that Gleason score agreement improved and the proportion of biopsy cores upgraded decreased from before 2005 to after 2005 [42]. However, many studies have demonstrated that age was independent predictor even if it was adjusted for year $[11,15,19,20,30]$. Even so, further long-term studies should also consider the version of grading system as a confounder.

It is highly debatable whether PCa progresses during long interval from biopsy to prostatectomy [43, 44]. It has been reported that actuarial risk of grade progression during 1-year follow-up was $3 \%$ among patients
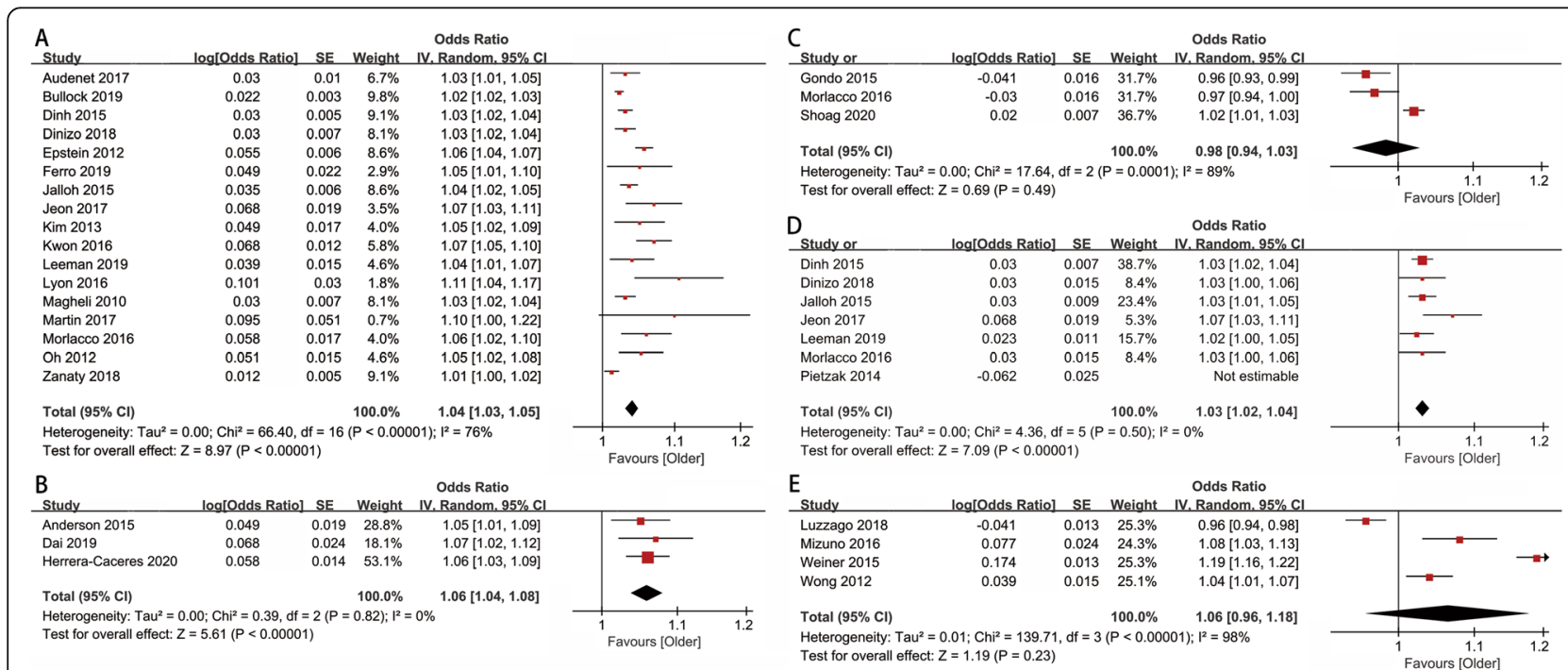

Fig. 2 Forest plot of age predicting. a Group A (upgrading from biopsy to prostatectomy). b Group B (upgrading from diagnostic biopsy to confirmatory biopsy). c Group C (downgrading from biopsy to prostatectomy). d Group D (upstaging). e Group E (upgrading and/or upstaging). An odds ratio of $>1$ indicates relative chance for older age versus younger age 


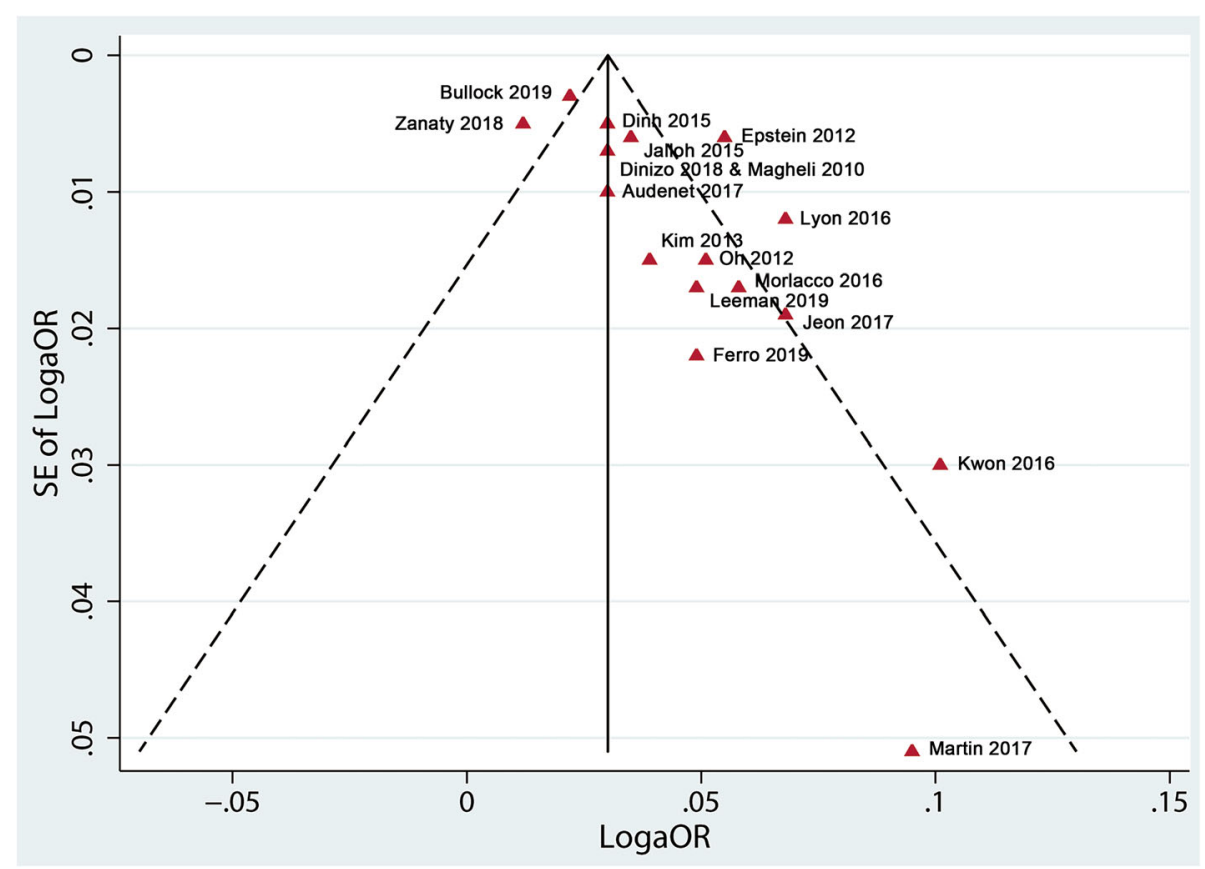

Fig. 3 Funnel plot of studies focused on age predicting upgrading from biopsy to prostatectomy

with Gleason 6 or less organ-confined tumors (11\% for 2 years) [45]. Even if the majority of studies did not report the intervals, we assumed that variability of time did not influence the comparison among studies. However, it is worth noticing that different intervals could be the potential source of heterogeneity.
Except the heterogeneity discussed above, our review has several limitations. First of all, there was variability in study designs among our included studies in which only a few focused on the predictive performance of age. Secondly, inevitable reasons such as unavailable full-text and non-extractable data resulted in incomplete retrieval

Table 4 Reasons of studies removed from meta-analysis in subgroup analysis

\begin{tabular}{|c|c|c|c|c|}
\hline Study & Non-organ confined disease & Not adjusted for PV & Not adjusted for no. cores & Study size $\leq \mathbf{3 0 0}$ \\
\hline Audenet 2017 [14] & $x$ & & $x$ & \\
\hline Bullock 2019 [15] & $x$ & $x$ & $x$ & \\
\hline Dinh 2015 [16] & & $x$ & & \\
\hline Dinizo 2018 [6] & & & $x$ & \\
\hline Epstein 2012 [17] & $\times$ & $x$ & $x$ & \\
\hline Ferro 2019 [18] & & & $x$ & $x$ \\
\hline \multicolumn{5}{|l|}{ Jalloh 2015 [19] } \\
\hline \multicolumn{5}{|l|}{ Jeon 2017 [10] } \\
\hline \multicolumn{5}{|l|}{ Kim 2013 [22] } \\
\hline Kwon 2016 [23] & & $x$ & $x$ & \\
\hline Leeman 2019 [11] & & $x$ & & \\
\hline Lyon 2016 [21] & $x$ & $x$ & & \\
\hline Magheli 2010 [24] & & & $x$ & \\
\hline Martin 2017 [25] & & & $x$ & $x$ \\
\hline \multicolumn{5}{|l|}{ Morlacco 2016 [5] } \\
\hline Oh 2012 [27] & & $x$ & & \\
\hline Zanaty 2018 [12] & & & $x$ & $x$ \\
\hline
\end{tabular}


of research. Moreover, most studies only consisted of population with low-risk PCa and focused mainly on disease reclassification from GS $\leq 6$ to higher, which might not represent the reality. Last but not least, different biopsy protocols influence detection rates of low-grade or high-grade diseases $[36,46]$. Different schemes of biopsy and different imaging guidance which were not reported in some studies also contribute to significant variation in outcomes.

\section{Conclusions}

Age is an independent predictor for both Gleason score upgrading and pathological upstaging. Combined with other prognostic factors, thorough consideration of age not only prompts more accurate risk stratification but also helps providers to select optimal therapies for patients with prostate cancer. Nevertheless, further robust studies are necessitated to confirm these results in the context of effect sizes for other factors such as PSA, number of positive cores, and race.

\section{Supplementary Information}

The online version contains supplementary material available at https://doi. org/10.1186/s12957-021-02127-3.

Additional file 1: Figure 1 The full PubMed search strategy.

Additional file 2: Figure 2 Plot of Egger's test studies focused on age predicting upgrade from biopsy to prostatectomy.

\section{Abbreviations \\ PCa: Prostate cancer; AS: Active surveillance; GS: Gleason score; PSA: Prostate- specific antigen; PRISMA: Preferred Reporting Items for Systematic Reviews and Meta-analysis; MVA: Multivariate analysis; PV: Prostate volume; aOR: Adjusted odds ratio; Cl: Confidence interval; NOS: Newcastle-Ottawa Quality Assessment Scale; IQR: Interquartile range; logaOR: Log-transformed aOR; SE: Standard error}

\section{Acknowledgements}

Not applicable.

\section{Authors' contributions}

$X W$ was a major contributor in conception and writing the manuscript. XW, $Y Z$, and ZI searched the databases, selected the eligible articles, and extracted data from literatures. ZJ and PY appraised the quality of included literatures. PY and YT supervised the work and substantively revised it. All authors read and approved the final manuscript and have agreed both to be personally accountable for the authors' own contributions and to ensure that questions related to the accuracy or integrity of any part of the work, even ones in which the author was not personally involved, are appropriately investigated, resolved, and the resolution documented in the literature.

\section{Funding}

Not applicable.

\section{Availability of data and materials}

All data generated or analyzed during this study are included in this published article [and its supplementary information files].

Ethics approval and consent to participate Not applicable.
Consent for publication

Not applicable.

\section{Competing interests}

The authors declare that they have no competing interests.

Received: 4 September 2020 Accepted: 11 January 2021

Published online: 20 January 2021

\section{References}

1. Mottet N, Cornford P, van den Bergh RCN, et al. EAU - EANM -ESTRO - ESUR - SIOG guidelines on prostate cancer. Arnhem, The Netherlands: European Association of Urology Guidelines Office; 2020.

2. Fenton JJ, Weyrich MS, Durbin S, et al. Prostate-specific antigen-based screening for prostate cancer: evidence report and systematic review for the us preventive services task force. JAMA. 2018:319:1914-31.

3. Johansson JE, Holmberg L, Johansson S, et al. Fifteen-year survival in prostate cancer. A prospective, population-based study in Sweden. JAMA. 1997:277:467-71.

4. Cohen MS, Hanley RS, Kurteva T, et al. Comparing the Gleason prostate biopsy and Gleason prostatectomy grading system: the Lahey Clinic, Medical Center experience and an international meta-analysis. Eur Urol. 2008:54:371-81.

5. Morlacco A, Cheville JC, Rangel LJ, et al. Adverse disease features in Gleason score $3+4$ "favorable intermediate-risk"prostate cancer: implications for active surveillance. Eur Urol. 2016;72:442-7.

6. Dinizo M, Shih W, Kwon YS, et al. Multi-institution analysis of racial disparity among African-American men eligible for prostate cancer active surveillance. Oncotarget. 2018;9:21359-65.

7. Kovac E, Vertosick EA, Sjoberg DD, et al. Effects of pathological upstaging or upgrading on metastasis and cancer-specific mortality in men with clinical low-risk prostate cancer. BJU Int. 2018:122:1003-9.

8. Bakavičius A, Drevinskaitè M, Daniūnaitè $K$, et al. The impact of prostate cancer upgrading and upstaging on biochemical recurrence and cancerspecific survival. Medicina (Kaunas). 2020;56:61.

9. Gondo T, Poon BY, Matsumoto K, et al. Clinical role of pathological downgrading after radical prostatectomy in patients with biopsy confirmed Gleason score $3+4$ prostate cancer. BJU Int. 2015;115:81-6.

10. Jeon $\mathrm{HG}$, Yoo JH, Jeong $\mathrm{BC}$, et al. Comparative rates of upstaging and upgrading in Caucasian and Korean prostate cancer patients eligible for active surveillance. PLoS One. 2017;12:e186026.

11. Leeman JE, Chen $\mathrm{MH}$, Huland $\mathrm{H}$, et al. Advancing age and the odds of upgrading and upstaging at radical prostatectomy in men with Gleason score 6 prostate cancer. Clin Genitourin Cancer. 2019;17:e1116-21.

12. Zanaty M, Ajib K, Zorn K, et al. Functional outcomes of robot-assisted radica prostatectomy in patients eligible for active surveillance. World J Urol. 2018; 36:1391-7.

13. Liberati A, Altman DG, Tetzlaff J, et al. The PRISMA statement for reporting systematic reviews and meta-analyses of studies that evaluate healthcare interventions: explanation and elaboration. BMJ. 2009;339:b2700.

14. Audenet F, Rozet F, Resche-Rigon M, et al. Grade group underestimation in prostate biopsy: Predictive factors and outcomes in candidates for active surveillance. Clin Genitourin Cancer. 2017;15:e907-13.

15. Bullock N, Simpkin A, Fowler S, et al. Pathological upgrading in prostate cancer treated with surgery in the United Kingdom: trends and risk factors from the British Association of Urological Surgeons Radical Prostatectomy Registry. BMC Urol. 2019;19:94.

16. Dinh KT, Mahal BA, Ziehr DR, et al. Incidence and predictors of upgrading and up staging among 10,000 contemporary patients with low risk prostate cancer. J Urol. 2015;194:343-9.

17. Epstein JI, Feng Z, Trock BJ, et al. Upgrading and downgrading of prostate cancer from biopsy to radical prostatectomy: incidence and predictive factors using the modified Gleason grading system and factoring in tertiary grades. Eur Urol. 2012;61:1019-24.

18. Ferro M, Musi G, Serino A, et al. Neutrophil, platelets, and eosinophil to lymphocyte ratios predict Gleason score upgrading in low-risk prostate cancer patients. Urol Int. 2019;102:43-50.

19. Jalloh M, Myers F, Cowan JE, et al. Racial variation in prostate cancer upgrading and upstaging among men with low-risk clinical characteristics. Eur Urol. 2015;67:451-7. 
20. Luzzago S, Musi G, Catellani M, et al. Multiparametric magnetic-resonance to confirm eligibility to an active surveillance program for low-risk prostate cancer: Intermediate time results of a third referral high volume centre active surveillance protocol. Urol Int. 2018;101:56-64.

21. Lyon TD, Turner RN, Yabes JG, et al. Preoperative statin use at the time of radical prostatectomy is not associated with biochemical recurrence or pathologic upgrading. Urology. 2016;97:153-9.

22. Kim KH, Lim SK, Shin TY, et al. Upgrading of Gleason score and prostate volume: a clinicopathological analysis. BJU Int. 2013;111:1310-6.

23. Kwon YS, Han CS, Yu JW, et al. Neutrophil and lymphocyte counts as clinical markers for stratifying low-risk prostate cancer. Clin Genitourin Cancer. 2016; 14:e1-8.

24. Magheli A, Hinz S, Hege C, et al. Prostate specific antigen density to predict prostate cancer upgrading in a contemporary radical prostatectomy series: a single center experience. J Urol. 2010;183:126-31.

25. Martin $\mathrm{NE}$, Chen $\mathrm{MH}$, Zhang $\mathrm{D}$, et al. Unfavorable intermediate-risk prostate cancer and the odds of upgrading to Gleason 8 or higher at prostatectomy. Clin Genitourin Cancer. 2017;15:237-41.

26. Mizuno $\mathrm{K}$, Inoue $\mathrm{T}$, Kinoshita $\mathrm{H}$, et al. Evaluation of predictors of unfavorable pathological features in men eligible for active surveillance using radical prostatectomy specimens: a multi-institutional study. Jpn J Clin Oncol. 2016; 46:1156-61.

27. Oh JJ, Hong SK, Lee JK, et al. Prostate-specific antigen vs prostate-specific antigen density as a predictor of upgrading in men diagnosed with Gleason 6 prostate cancer by contemporary multicore prostate biopsy. BJU Int. 2012;110:E494-9.

28. Pietzak ER, Kabarriti AE, Mucksavage $P$, et al. The presence of high-grade prostatic intraepithelial neoplasia or atypia on prostate biopsy does not adversely affect prostatectomy outcomes for patients otherwise eligible for active surveillance. Urology. 2014;84:1442-7.

29. Shoag JE, Cai PY, Gross MD, et al. Impact of prebiopsy magnetic resonance imaging on biopsy and radical prostatectomy grade concordance. Cancer. 2020;126:2986-90.

30. Weiner AB, Patel SG, Eggener SE. Pathologic outcomes for low-risk prostate cancer after delayed radical prostatectomy in the United States. Urol Oncol. 2015;33:111-64.

31. Wong LM, Neal DE, Johnston RB, et al. International multicentre study examining selection criteria for active surveillance in men undergoing radical prostatectomy. Br J Cancer. 2012;107:1467-73.

32. Anderson CB, Sternberg IA, Karen-Paz G, et al. Age is associated with upgrading at confirmatory biopsy among men with prostate cancer treated with active surveillance. J Urol. 2015;194:1607-11.

33. Dai C, Ganesan V, Nyame YA, et al. Older age at diagnosis and initial disease volume predict grade reclassification risk on confirmatory biopsy in patients considered for active surveillance. Urology. 2019;130:106-12.

34. Herrera-Caceres JO, Wettstein MS, Goldberg $\mathrm{H}$, et al. Utility of digital rectal examination in a population with prostate cancer treated with active surveillance. Can Urol Assoc J. 2020;14:E453-7.

35. Luo D, Wan X, Liu J, et al. Optimally estimating the sample mean from the sample size, median, mid-range, and/or mid-quartile range. Stat Methods Med Res. 2018;27:1785-805.

36. Capitanio U, Karakiewicz PI, Valiquette L, et al. Biopsy core number represents one of foremost predictors of clinically significant gleason sum upgrading in patients with low-risk prostate cancer. Urology. 2009;73:1087-91.

37. Muralidhar V, Dinh KT, Mahal BA, et al. Differential post-prostatectomy cancer-specific survival of occult T3 vs. clinical T3 prostate cancer: Implications for managing patients upstaged on prostate magnetic resonance imaging. Urol Oncol. 2015;33:330-e19-25.

38. Oderda M, Gontero P, Sanchez-Salas R, et al. Gleason score upgrading to 810 predicts biochemical recurrence in patients undergoing radical prostatectomy: Analysis on 7310 high-risk patient the EMPaCT database. Eur Urol Suppl. 2015;14:e936

39. Salari K, Kuppermann D, Preston MA, et al. Active surveillance of prostate cancer is a viable option for men younger than 60 years. J Urol. 2019;201: 721-7.

40. Brassell SA, Rice KR, Parker PM, et al. Prostate cancer in men 70 years old or older, indolent or aggressive: clinicopathological analysis and outcomes. J Urol. 2011;185:132-7.

41. Delahunt B, Egevad L, Samaratunga H, et al. Gleason and Fuhrman no longer make the grade. Histopathology. 2016;68:475-81.
42. Danneman D, Drevin L, Delahunt B, et al. Accuracy of prostate biopsies for predicting Gleason score in radical prostatectomy specimens: nationwide trends 2000-2012. BJU Int. 2017;119:50-6.

43. Nam RK, Jewett MAS, Krahn MD, et al. Delay in surgical therapy for clinically localized prostate cancer and biochemical recurrence after radical prostatectomy. Can J Urol. 2003;10(3):1891.

44. Khan MA, Mangold LA, Epstein Jl, et al. Impact of surgical delay on longterm cancer control for clinically localized prostate cancer. J Urol. 2004;172: 1835-9.

45. Sheridan TB, Carter HB, Wang W, et al. Change in prostate cancer grade over time in men followed expectantly for stage T1c disease. J Urol. 2008; 179:901-4 904-905.

46. Siddiqui MM, Rais-Bahrami S, Truong H, et al. Magnetic resonance imaging/ ultrasound-fusion biopsy significantly upgrades prostate cancer versus systematic 12-core transrectal ultrasound biopsy. Eur Urol. 2013;64:713-9.

\section{Publisher's Note}

Springer Nature remains neutral with regard to jurisdictional claims in published maps and institutional affiliations.

Ready to submit your research? Choose BMC and benefit from:

- fast, convenient online submission

- thorough peer review by experienced researchers in your field

- rapid publication on acceptance

- support for research data, including large and complex data types

- gold Open Access which fosters wider collaboration and increased citations

- maximum visibility for your research: over $100 \mathrm{M}$ website views per year

At BMC, research is always in progress.

Learn more biomedcentral.com/submissions 